\title{
The Expression of CD8+ and MHC-I in Cervical Cancer with HPV Infection
}

\author{
Adi Prayitno ${ }^{1}$, Elyana Asnar ${ }^{2}$, Okid Parama Astirin ${ }^{3}$, Suhartono Taat Putra ${ }^{2}$ \\ ${ }^{1}$ Medical School of Sebelas Maret University, Surakarta, Indonesia; ${ }^{2}$ Medical School of Airlangga University, Surabaya, Indonesia; \\ ${ }^{3}$ Mathematical and Science Faculty of Sebelas Maret University, Surakarta, Indonesia. \\ Email: drgadiprayitno@yahoo.com
}

Received March 17 ${ }^{\text {th }}, 2013$; revised April 16 ${ }^{\text {th }}, 2013$; accepted April 23 ${ }^{\text {rd }}, 2013$

Copyright (c) 2013 Adi Prayitno et al. This is an open access article distributed under the Creative Commons Attribution License, which permits unrestricted use, distribution, and reproduction in any medium, provided the original work is properly cited.

\begin{abstract}
Introduction: The immunity against cervical cancers is many unknown. Major histocompatability complex class I (MHC-I) with the alpha domain has binding site for Cytotoxic T cells (CD8+) to target cells. The objective of this experiment is to know the expression of CD8+ and MHC-I in cervical cancer with HPV infection. Method: DNA was isolated from seventeen sample cervical cancer tissues frozen section. Diagnose related with HPV was made by PCR. Paraffin block of the tissues was cut in thoroughly cleaned cryotome and place in glass plate that covered with poly-elysine. The immunohistochemistry is done with monoclonal antibody again MHC-I and CD8+ with TSA-indirect method. The power of expression was counted the number of positive cells to express the MHC-I and CD8+ every 100 cells per one view look. Result: The result of this experiment shows that expression of MHC-I and CD8+ in cervical cancer with HPV infection is in mild category (30\% - 70\%). Conclusion: Immunity against uterine cancer played by MHC-I and CD8+ is in milt category. The experiment that related with uterine cancer immunology is suggested.
\end{abstract}

Keywords: CD8+; MHC-I; HPV; Cervical Cancer

\section{Introduction}

Cervical cancer is the most common form neoplasm in women. This neoplasm is found in developing state as leading cause of neoplasm-related deaths in women in the world as a whole. Now the pathogenesis of cervical cancer is focused to human papilloma virus (HPV) [1-3]. Immunity to neoplasm or cancer as a whole are decided by Cytotoxic T Lymphocyte cells (CD8+, CTL, Tc), natural killer (NK) cells and specific antibody [4-10].

Immunity to destroy viruses to be many ways like interferon, secretory Immunoglobulin A (s-Ig A) of epithelial surface, antibody dependent cellular cytotoxicity (ADCC), and NK-cells, and more difficult to be sure which one are important [8-13]. Identity of TSAs (tumor-specific antigens) in experimentally induced tumors and their existence on human tumors remained elusive until the molecular basis of $\mathrm{T}$ lymphocyte cell recognition was understood. With realization that $\mathrm{T}$ lymphocyte cell receptors recognize peptides bound to the antigenbinding cleft of major histocompatability complex molecules class I [4-7].

CD8+ is a lymphocyte that kills other cells. CD8+ rec- ognized class I alloantigens or conventional antigens (e.g., viruses) associated with class I histocompatability molecules [5-8].

MHC-I molecules are integral membrane proteins found on all nucleated cell and platelets. The extracellular portion has three domains. The alpha-3 domain has a binding site for CD8+. CD8+ $\mathrm{T}$ lymphocytes kill target cells when they recognize antigen in associated with self MHC-I [5-8].

\section{Material and Method}

Frozen section tissues are collected from obstetric and gynecologic part of doctor Muwardi Hospital Surakarta patient with cervical cancer from January 2001 to January 2002.

DNA isolation was made by Henk Schmits method with some modifications [9]. Cut up to $25 \mathrm{mgr}$ of tissue into small pieces, place in $1.5 \mathrm{ml}$ a microfuge tube volume, and add $200 \mathrm{ul}$ of DNA extraction buffer. Add $20 \mathrm{ul}$ of Proteinase $\mathrm{K}$ stock solution, mix by vortexing, and incubate at $55^{\circ} \mathrm{C}$ overnight.

Diagnose related with HPV infections are made by Henk Schmits and/or Nigel McMillan and Nina Fowler 
PCR-method with some modifications [9,10]. Twenty five ul microfuge tube Ready To Go PCR Bead (Amersham Pharmacia Biotech) mixed with 2 ul HPV consensus primers (MY09 and MY11) (CYBERGENE AB) and 2 ul DNA template. PCR protocol for both amplifications are $94^{\circ} \mathrm{C}$ for 50 seconds, $59^{\circ} \mathrm{C}$ for 50 seconds, $72^{\circ} \mathrm{C}$ for 50 seconds and $4^{\circ} \mathrm{C}$ soak.

Paraffin-embedded tissue cervical cancer with HPV infection are cut using a thoroughly cleaned microtome and placed in glass plate that covered with poly-elisen. Immunohistochemistry stain is done with TSA-indirect method (NEN Life Science Products, RENAISSENCE) used monoclonal antibody again MHC-I (1:500) and CD8+ (1:500) produced by Santa Cruz. Photo microscopic collected via aX100 objective lens.

\section{Result and Discussion}

From gel electrophoresis (Figure 1) can look the 450 band of DNA L1-HPV virus.

Neoplasm of the cervical uterine is the most common form neoplasm in women. This neoplasm is found in developing state as leading cause of neoplasm-related deaths in women in the world as a whole. The mortality rate has been estimated at 2.8 deaths per 100,000 women, with a total of 252 deaths reported in 1993. Now the pathogenesis of cervical cancer is pointed to human papilloma virus (HPV). HPV infection associated with malignancies of urogenital tract and anus and also thought to be related to disorder of skin and the upper-respiratory tract [1-3].

Immunity to cancer as a whole is decided by Cytotoxic T cells, NK-cells and specific antibody [4-10], otherwise to destroy viruses of human have many ways, and more difficult to be sure which one is important. Number ways are Interferon, s-Ig A of epithelial surface, antibody and antibody dependent cytotoxic cell (ADCC), and NK-cells [5-8,11-17]. Cytokines are included in the mechanism of immunity to cancer.

From immunohistochemistry stain can look in Figures $\mathbf{2}$ and $\mathbf{3}$ and Table 1 for CD8+ expression and Figures $\mathbf{4}$ and $\mathbf{5}$ and Table $\mathbf{2}$ for MHC-I expression.

Cytotoxic T cell (CTL, Ts, CD8+) is a T lymphocyte cell that kills other cells. Most CTL are CD8+; these cell recognize class I alloantigens or conventional antigens (e.g. viruses) associated with self class I histocompata-

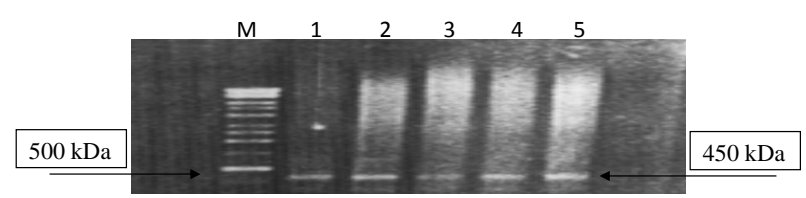

Figure 1. Gel electrophoresis the 5 sample with HPV positive. The band about 450 bp long are the DNA HPV from L1 gene amplified (arrow). M: Marker.

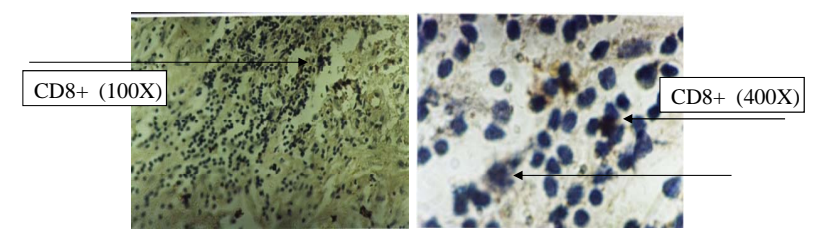

Figure 2. Immunohistochemistry staining of CD8+. The yellow-dark show that the CD8+ (black arrow) are expressed in this tissue with cervical cancer.

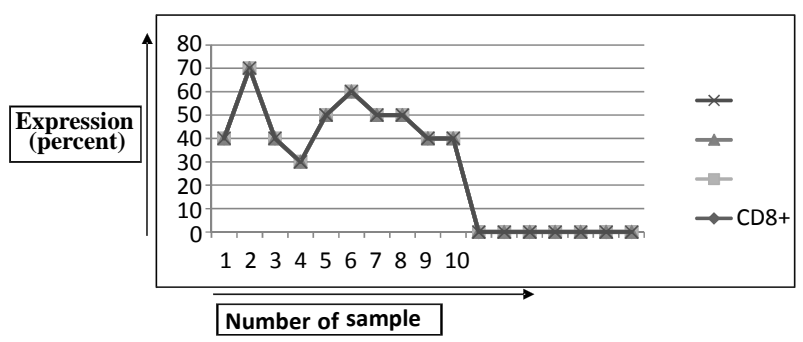

Figure 3. Expression of CD8+ from 10 sample cervical cancer with HPV infection.

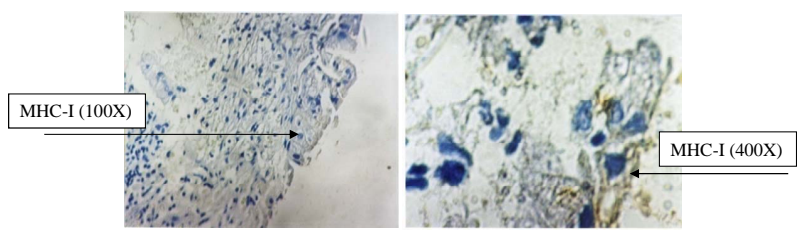

Figure 4. Immunohistochemistry staining of MHC-I. The yellow-dark show that the MHC-I (black arrow) are expressed in this tissue with cervical cancer.

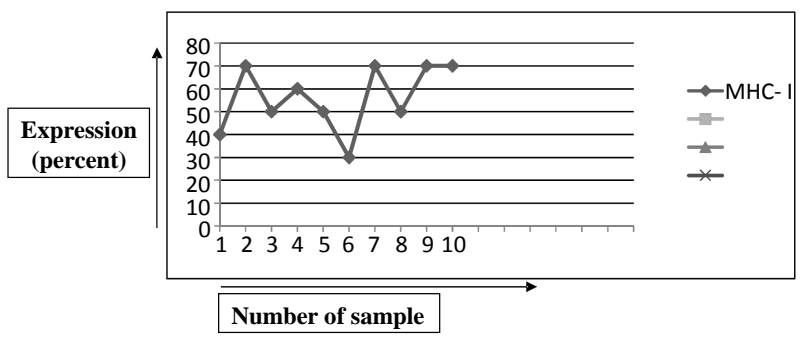

Figure 5. Expression of MHC-I from 10 sample cervical cancer with HPV infection.

bility molecule. Some CTL are CD4+; these cells recognize antigens associated with class II alloantigens or self class II histocompatability molecule. The mechanism of killing has been studied in detail with CD8+ T lymphocytes. Once a cytotoxic $\mathrm{T}$ lymphocyte has recognized antigen, it binds to the target cell and kills it within a few hours. The mechanism of taget killing is not well understood and appears to include release of trypsin-like serine proteases, and cytotoxic lymphokine (e.g. perforin) [5-8, 11-19].

Genetic loci involved in the rejection of foreign tissue or non-self-forming region known as MHC. Structure is highly polymorphic cell surface that are involved in the 
Table 1. Expression of CD8+ (in percent) from 10 sample cervical cancer with HPV infection.

\begin{tabular}{cc}
\hline No. of sample & CD8+ (\%) \\
\hline 1. & 40 \\
2. & 70 \\
3. & 40 \\
4. & $30^{*}$ \\
5. & 50 \\
6. & 60 \\
7. & 50 \\
8. & 50 \\
9. & 40 \\
10. & 40 \\
Mean & 47 \\
\hline
\end{tabular}

Percentage is got from cells positif/ 100 cells/one view look 5\% - 30\%: light expression category $\left({ }^{*}\right)$; $31 \%$ - 70\%: mild expression category; $71 \%$ - 100\%: hard expression category.

Table 2. Expression of MHC-I (in percent) from 10 sample cervical cancer with HPV infection.

\begin{tabular}{cc}
\hline No. of sample & MHC-I (\%) \\
\hline 1. & 40 \\
2. & 70 \\
3. & 50 \\
4. & 60 \\
5. & 50 \\
6. & $30^{*}$ \\
7. & 70 \\
8. & 50 \\
9. & 70 \\
10. & 70 \\
Mean & 57
\end{tabular}

Percentage is got from cells positif/100 cells/one view look 5\% - 30\%: light expression category $\left({ }^{*}\right)$; $31 \%-70 \%$ : mild expression category; $71 \%-100 \%$ : hard expression category.

rejection, which is called MHC antigen, which was initially characterized by alloantibodies produced in one strain of inbred mice immunized with cells from other types only differ in the MHC. The same technique is used to determine the human MHC, which is known as antigen (HLA) system of human leukocytes. Three classes have been identified as encoded in murine and human MHCs. MHC-I consists of a glycosylated heavy chain (45 kDa) non-covalent assosiated with microglobuline beta-2 $(12 \mathrm{kDa})$ polypeptide that is also found in the serum-free [12-14,16]. MHC-I molecules are integral membrane proteins found in all nucleated cells and platelet. The alpha-3 domain has a binding site for Cytotoxic $\mathrm{T}$ cells. Cytotoxic $\mathrm{T}$ cells kill target cells when they recognize antigen in association with self MHC-I molecules [5-8,14,20-25].

\section{Conclution}

The result of this experiment shows that expression of CD8+ and MHC-I in cervical cancer with HPV infection are in mild category $(30 \%-70 \%)$.

\section{Acknowledgements}

We thank to acknowledge DCRG-URGE Project 2001, Inter University Center for Biotechnology of Gajah Mada University and special thanks to acknowledge Noerhayati Soeripto as a lecturer, Zainal Arifin as a dean of Medical Faculty Sebelas Maret University, Basuki Sutarjo as a top manager of Muwardi Public Hospital and Yekti Widjajati as manager of Pathology Instalation of of Medical Faculty Sebelas Maret University.

\section{REFERENCES}

[1] G. Schmits, "Overview: Epidemiology and Diagnosis of Cervical Cancer,” Proceeding Seminar Nasional Upaya Peningkatan Deteksi HPV Pada Kanker Serviks Secara Biologi Molekuler Dan Pengelolaannya. Pusat Kedokteran Tropis, Gajah Mada University, Yogyakarta, 1997, pp. 1-42.

[2] A. Prayitno, "Cervical Cancer with Human Papilloma virus and Epstein Barr virus Positif,” Journal of Carcinogenesis, Vol. 5, No. 13, 2006, pp. 1-4. doi:10.1186/1477-3163-5-13

[3] L. Pusztai, C. E. Lewis and E. Yap, "Cell Proliferation in Cancer-Regulation Mechanisms of Neoplastic Cell Growth,” Oxford University Press, Oxford, New York, Tokyo, 1996.

[4] R. S. Cotrans, V. Kumar and S. L. Robbins, "Robbins Patologic Basis of Disease,” 6th Edition, WB Saunders Co., London, 1997, pp. 604-607.

[5] D. Male, “Immunologi: An Illustrated Online,” 2nd Edition, Mosby, St. Louis, Toronto, 1994.

[6] A. Venuti, "Progress and Challenges in the VaccineBased Treatment of Head and Neck Cancers," Journal of Experimental \& Clinical Cancer Research, Vol. 28, No. 69, 2009. doi:10.1186/1756-9966-28-69

[7] O. J. Finn, “Cancer Immunology,” New England Journal of Medicine, Vol. 358, 008, pp. 2704-2715.

[8] C. L. Berger, N. Wang, I. Christensen, J. Longley, P. Heald and R. L. Edelson, "The Immune Response to Class I-Associated Tumor-Specific Cutaneous T-Cell Lymphoma Antigens," Journal of Investigative Derma- 
tology, Vol. 107, 1996, pp. 392-397. doi:10.1111/1523-1747.ep12363378

[9] H. L. Smits, "Species Diagnostics Protocols: PCR and Other Nucleic Acid Methods,” In: J. P. C. Humana, Ed., Methods in Molecular Biology, Press Inc., Totowa, 1994.

[10] M. Nigel and F. Nina, "Typing of HPV Isolates by PCR: Molecular Approach Toward Vaccine Development for Viral Infection. Icro-Unesco Training Course, At Inter University Center for Biotecnology,” Gajah Mada University, Yogyakarta, 1998.

[11] J. H. L. Playfair, “Immunology at a Glance,” 5th Edition, Blackwell Scientific Publications, London, 1993.

[12] I. Roitts, J. Brostoff and D. Male, "Immunology," 3rd Edition, Mosby, St. Louis, Toronto, 1993.

[13] F. S. Rosen, L. Steiner and E. R. Unanue, "Macmillan Dictionary of Immunology,” Macmillan Reference Books, 1989.

[14] D. P. Stites and A. I. Terr, "Basic Human Immunology," 1st Edition, Prentice-Hall International Inc., Connecticut, 1991, pp. 34-44.

[15] S. Cornain, "Immune Response against Viral Infection: Molecular Approach toward Vaccine Development for Viral Infection. Icro-Unesco Training Course, At Inter University Center for Biotecnology," Gajah Mada University, Yogyakarta, 1998.

[16] R. S. Cotrans, V. Kumar and S. L. Robbins, "Robbins Patologic Basis of Disease," 6th Edition, WB Saunders Co., London, 1999, pp. 604-607.

[17] J. J. Stein, "Virology, Immunology, and Immunotherapy of Malignant Disease,” Cancer, Vol. 34, No. 4, 1974, pp. 1343-1346.

[18] R. M. Welsh, L. K. Selin and E. Szomolanyi-Tsuda, "Immunological Memory to Viral Infections," Annual Review of Immunology, Vol. 22, 2004, pp. 711-743. doi:10.1146/annurev.immunol.22.012703.104527

[19] S. Koyama, T. Ebihara and K. Fukao, "Expression of Intercellular Adhesion Molecule 1 (ICAM-1) during the Development of Invasion and/or Metastasis of Gastric Carcinoma,” Journal of Cancer Research and Clinical Oncology, Vol. 118, No. 8, 1992, pp. 609-614. doi:10.1007/BF01211806

[20] K. G. Karnen, "Imunologi Dasar,” Penerbit Fakultas Kedokteran Universitas Indonesia, Jakarta, 1988, pp. 49-57.

[21] C. L. Berger, N. Wang, I. Christensen, J. Longley, P. Heald and R. L. Edelson, "The Immune Response to Class I-Associated Tumor-Specific Cutaneous T-Cell Lymphoma Antigens,” Journal of Investigative Dermatology, Vol. 107, 1996, pp. 392-397. doi:10.1111/1523-1747.ep12363378

[22] I. Galea, J. Stasakova, M. S. Dunscombe, C. H. Ottensmeier, T. Elliott and S. M. Thirdborough, "CD8+ T-Cell Cross-Competition Is Governed by Peptide-MHC Class I Stability,” European Journal of Immunology, Vol. 42, No. 1, 2012, pp. 256-263.

[23] M Naoe, Y Marumoto, R Ishizaki, Y Ogawa, Y Nakagami and H. Yoshida, "Correlation between Major His tocompatibility Complex Class I Molecules and CD8+ T Lymphocytes in Prostate, and Quantification of CD8 and Interferon-Gamma mRNA in Prostate Tissue Specimens,” BJU International, Vol. 90, No. 7, 2002, pp. 748-753.

[24] E. S. Jordanova, A. Gorter, Ou. Ayachi, F. Prins, L. G. Durrant, G. G. Kenter, S. H. van der Burg and G. J. Fleuren, "Human Leukocyte Antigen Class I, MHC Class I Chain-Related Molecule A, and CD8+/Regulatory T-Cell Ratio: Which Variable Determines Survival of Cervical Cancer Patients?" Clinical Cancer Research, Vol. 14, 2008, pp. 20-28.

[25] V. Richards, "Cancer Immunology,” California Medicine, Vol. 112, No. 4, 1970, p. 52. 